\title{
Frequency of Mine Dust Episodes and the Influence of Meteorological Parameters on the Witwatersrand Area, South Africa
}

\author{
Olusegun Oguntoke, Matthew E. Ojelede, and Harold J. Annegarn \\ Department of Geography, Environmental Management and Energy Studies, University of Johannesburg, P.O. Box 524, \\ Auckland Park, 2006, South Africa \\ Correspondence should be addressed to Olusegun Oguntoke; oluseguno@uj.ac.za
}

Received 30 April 2013; Accepted 26 September 2013

Academic Editor: Dimitris G. Kaskaoutis

Copyright ( 2013 Olusegun Oguntoke et al. This is an open access article distributed under the Creative Commons Attribution License, which permits unrestricted use, distribution, and reproduction in any medium, provided the original work is properly cited.

\begin{abstract}
Aeolian dispersal of dust from gold mine tailing storage facilities impacts negatively on amenities, human health, and the environment of the Witwatersrand region, South Africa. The present study adopted a multivariate analytical method to quantify the effect of specific meteorological parameters on dust fall emissions, monitored at 22 sites in the central Witwatersrand area. Using meteorological and dust fall data from 2001 to 2010, the relationships between weather and dust fallout deposition rates were explored across the sites at different seasons. Dust deposition rate varied among seasons, with spring months showing the highest levels and frequency. Atmospheric humidity had negative correlations $(r=-0.25-0.59)$ with dust fall while wind speed showed positive correlations $(r=0.28-0.58)$ at the selected sites $(P<0.05)$. Sites with low influence of relative humidity had higher impact on wind speed. Mean relative humidity below $50 \%$ and mean wind speed above $4 \mathrm{~m} / \mathrm{s}$ were predicted as critical levels for dust episodes incidence at sites that recorded "heavy" and "very heavy" dust fall. For environmental planning purposes, current mitigation measures should be manipulated in relation to levels of air humidity and wind speed for dust emission reduction, especially during spring.
\end{abstract}

\section{Introduction}

Pollution arising from tailing storage facilities (TSFs) which serve as depository for waste materials generated in gold mining process has been source of concern to communities situated in their precinct. In the Witwatersrand area, residents of communities located within the buffer zone of TSFs are particularly concerned about their frequent exposure to airborne particulate matter associated with wind erosion of TSFs. Such concern has drawn public attention owing to the perceived negative impacts of mine waste materials on the health and safety of local communities and the environment, at large. Apart from wind-blown dust pollution that characterizes mine sites, soil and water contamination, unstable slopes on dumps, use of explosives, and presence of radioactive materials are other sources of concern in the Witwatersrand area $[1,2]$.
Dustfall consists largely of coarse or settleable particulate matter ( $>30 \mu \mathrm{m}$ diameter) which constitutes approximately 40 percent of dust from mine source materials. The remaining proportion consists of finer particulates, of which the concentration of $\mathrm{PM}_{10}$ ranges from 22-38 to $11-26 \mathrm{vol} \%$ in recent and older slimes [3]. Specifically, settleable dust impairs visibility when it forms dust plumes while its deposition on fabrics, buildings, vehicles, and water tanks constitutes a nuisance [4]. The ongoing reprocessing of sand and slime tailings to finer materials for gold recovery is aggravating dust pollution and the consequent further deterioration of ambient air quality in the Witwatersrand area [5, 6]. Residents of affected communities in the Witwatersrand region often complained about nuisance resulting from dust deposition, which causes loss of property value, damaged factory machineries, and disease conditions. 
Despite ongoing research to ascertain the health implications of tailings dust in the Witwatersrand region, previous studies have confirmed increased hospital admission, emergency room visit, and mortality among patients of respiratory ailments [7, 8]. Many epidemiological studies have linked levels of ambient particulate matter with a variety of human health problems such as silicosis, pneumoconiosis, and increased risk of tuberculosis, lung cancer, scleroderma, and systemic lupus erythematous $[9,10]$. Specifically, exposure to gold mine dust, that is, rich in silica, has been linked to the development of chronic bronchitis, emphysema, and air flow obstruction $[11,12]$.

There are quite a number of factors that influence dust pollution and dispersal in mining environment [13, 14]. Assessing the role of climate, Mishra and Shambhu [14] observed that dust generation varied significantly in the premonsoon, postmonsoon, and winter periods. Furthermore, Wallace and Ott [15] indicated that locations found downwind of mine sites experienced higher dust concentration than others upwind. According to Scorgie [16] and Annegarn and Sithole [17], spring months are identified as critical periods of dust storm episodes in the Witwatersrand region. Taking an overview of the severity of dust erosion from TSFs in the study area, weather events are identified as predominant determinant factors.

To date, policy measures for control of mining impacts in the study area are focused on the minimization and mitigation of wind-blown dust [18-20]. In the region, particle size distribution and characterization of mine dust have been investigated $[1,21,22]$ in addition to impact of dust on aspects of the environment [23]. Nevertheless, the underlying factors of seasonal occurrence of dust episodes and the consequent community outcry have not been sufficiently explored. While environmental policy aimed at limiting levels of dustfall exists in South Africa and the mine operators strive to curtail dust emission from TSFs, dustfall exceedance is recurrent. The permissible limits of dustfall in residential and industrial areas are $\leq 600 \mathrm{mg} / \mathrm{m}^{2} / \mathrm{d}^{-1}$ and $\leq 1200 \mathrm{mg} / \mathrm{m}^{2} / \mathrm{d}^{-1}$, respectively. Exceedance of these levels by any mineral exploring company in South Africa is allowed only thrice a year but not in two sequential months [24]. While international limits for dustfall levels are rare, the relevant agencies in South Africa have tried to enforce the abovementioned limits in order to protect the populace.

The present study investigated the interactions between pattern of dustfall and specific meteorological parameters using a multivariate analytical method. In addition, it quantified the influence of meteorological parameters on the levels of wind-blown mine dust from gold TSFs in Witwatersrand area. A good understanding of the specific effects of meteorological factors on mine dust emission is capable of aiding optimal allocation of resources and intervention planning in residential areas.

\section{Materials and Method}

The Witwatersrand region is located in Gauteng province, the gold mining hub of South Africa. Gauteng province is located on high-altitude grassland called Highveld, about
1,500 $\mathrm{m}$ above mean sealevel. The climate is mostly influenced by subtropical weather systems. Even though the province is at subtropical latitude, the climate is comparatively cooler, especially in Johannesburg (1,700 m asl). Most precipitation occurs as brief afternoon thunderstorms; however, relative humidity never becomes uncomfortable. Winters are crisp and dry with frost occurring often in the southern areas. Snow is rare, but it has occurred on some occasions in the Johannesburg area [25].

At summer time especially January, average maximum and minimum temperature of Johannesburg are $26^{\circ} \mathrm{C}$ and $15^{\circ} \mathrm{C}$ while in winter (June) the average maximum and minimum temperature range between $16^{\circ} \mathrm{C}$ and $4^{\circ} \mathrm{C}$. Annual precipitation in the city is approximately $713 \mathrm{~mm}$. In Gauteng, summer days are warm and winter days are crisp, clear, and wind-free. There are about six weeks of cold weather in mid-winter (from July to August) and summer offers warm sunshine followed by balmy nights (from October to March). The rainy season is in summer rather than winter (JuneAugust). Rainstorms are often harsh accompanied by much thunder and lightning and occasional hail, but they are brief and followed by warm sunshine [25].

The study utilized data from two sources: data on dustfall monitored from 2001 to 2010 (Annegarn Environmental Research, now SGS) and meteorological data for the same period (from the South Africa Weather Service). Dustfall data were collected from Crown-Gold dust monitoring project (CRUST) in Johannesburg. The bucket collection technique adopted by CRUST for dustfall monitoring follows the American Society for Testing and Materials (ASTM D1739) [26]. The buckets, left on site for $30( \pm 3)$ days for dust collection, are partly filled with distilled water, to which a biocide is added to prevent the growth of algae. In the laboratory, the collected and preserved sample is filtered, dried, and weighed. The dustfall rate $(D)$ is determined by using the formulae

$$
D=\frac{W}{A}\left(\mathrm{mg} / \mathrm{m}^{2} / 30\right)
$$

where $W$ stands for mass of dust collected and $A$ is the area of the container used.

In the study area dustfall monitoring sites were grouped into nine zones, namely, Crown, City Deep, Heriotdale, Western, Fleurhof, Soweto, Robinson, Knights, and Mennel. Sites were randomly selected from eight zones with the exclusion of Mennel, where dust monitoring commenced only in 2005. In all, 12 residential and 10 nonresidential sites were selected as follows: Crown area (3 sites), City Deep area (2 sites), Heriotdale area (5 sites), Western area (2 sites), Fleurhof area (2 sites), Robinson area (2 sites), Soweto area (3 sites), and Knights area (3 sites); see Figure 1. The detailed description of the index numbers (codes) of the selected locations is presented in Table 4.

The meteorological data for OR Tambo International airport, which is the nearest weather station to the study area with complete daily records for 2001-2010, were used. Weather data on rainfall, air humidity (\%), temperature $\left({ }^{\circ} \mathrm{C}\right)$, air pressure, wind speed $(\mathrm{m} / \mathrm{s})$, and wind direction were retrieved from the agency. Minimum, maximum, and mean values of these parameters were computed on monthly 


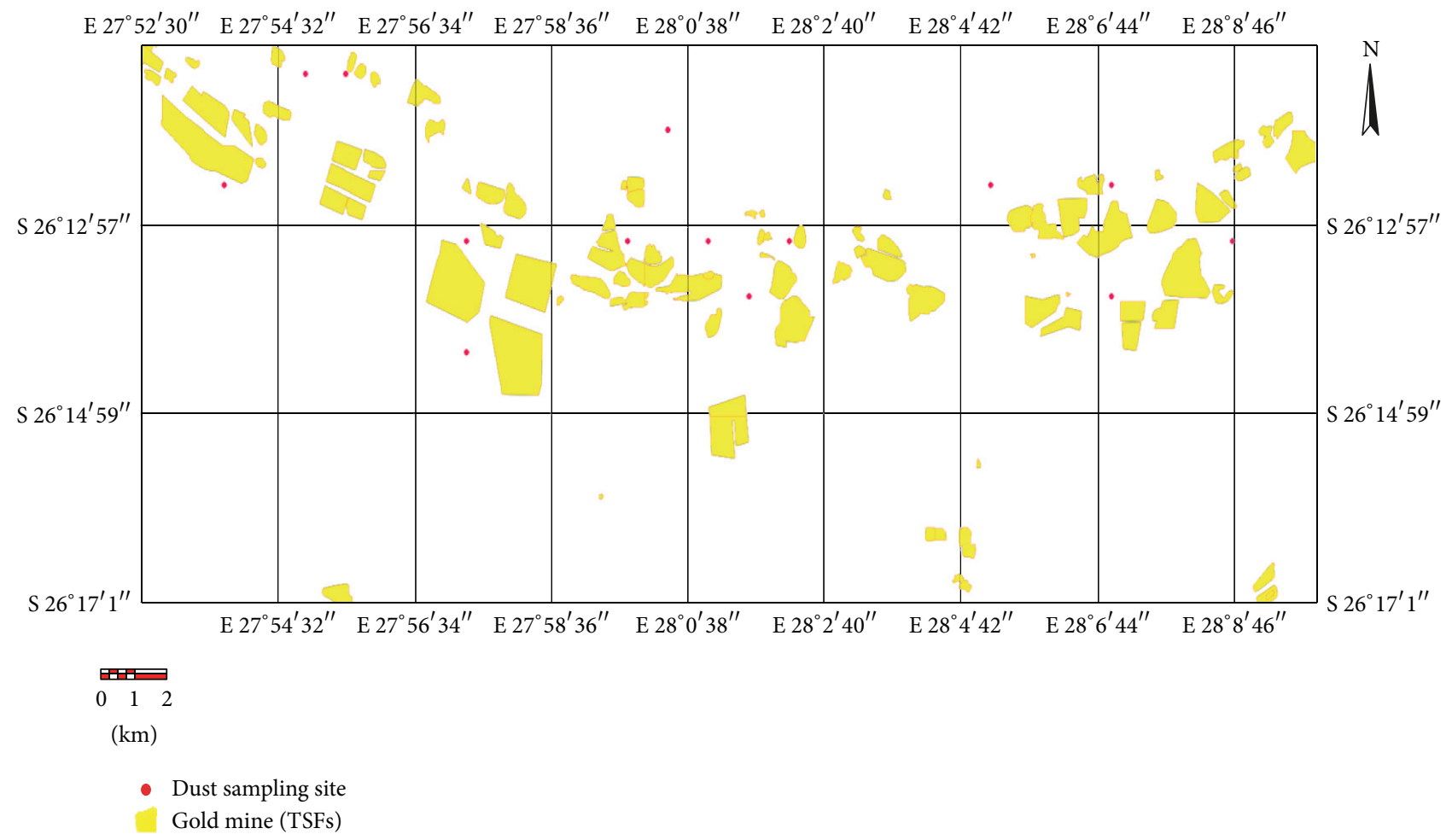

FIGURE 1: Location of selected dust monitoring sites in the Witwatersrand region.

basis and used as explanatory variables in correlation and regression analyses.

Dust data were analysed for seasonal patterns using Box and Whisker graphical presentation. Moreover, correlation analysis was employed to investigate the relationship between meteorological parameters and dustfall at each of the monitoring sites. In order to examine the contribution of meteorological parameters to dustfall levels, stepwise regression model was used. Based on the computation of mean, minimum, and maximum values for each of the six meteorological parameters, 18 parameters were generated. Employing these parameters in correlation analysis revealed that only 10 of them have significant correlation with dustfall at any of the sites. Furthermore, the 10 significant meteorological parameters were subjected to colinearity diagnostic test in order to make them fit for regression analysis. Two variables (mean pressure and maximum temperature) that failed the test $(r \geq 0.91)$ were also excluded from the regression analysis. Out of the eight parameters that were presented in the correlation analysis, only five had significant determination coefficients in the regression analysis.

The regression model is of the form

$$
Y=a+b_{1} X_{1}+b_{2} X_{2}+b_{3} X_{3} \cdots b_{n} X_{n}
$$

where $a$ stands for the intercept of model slope and $b_{1}-b_{n}$ are the quotients of the explanatory variables. The dustfall level at each site (dependent variables) was regressed on eight meteorological parameters (predictor variables) using stepwise option. All statistical tests were conducted using the statistical package for the Social Sciences (SPSS version 20 ) and the results considered significant at $P \leq 0.05$ [27].

\section{Results}

The mean dust levels during summer were generally below the $600 \mathrm{mg} / \mathrm{m}^{2} / \mathrm{d}$ limit for residential areas, although higher values $\left(700-1,600 \mathrm{mg} / \mathrm{m}^{2} / \mathrm{d}\right)$ were recorded at $8 \mathrm{JCCH}$, 57JCECL, and 50MOLLO (Crown, Robinson, and Soweto zones) on some occasions (Figure 2(a)). In nonresidential locations, mean dust levels were also below $1,200 \mathrm{mg} / \mathrm{m}^{2} / \mathrm{d}$ set for nonresidential environment (Figure 2(e)). Notwithstanding, 23IMP and 65KG MIN locations (Heriotdale and Knights zones) recorded dust emission between 2,500 and $3,500 \mathrm{mg} / \mathrm{m}^{2} / \mathrm{d}$ sometimes.

In autumn, mean dustfall monitored at residential and nonresidential sites was within the permissible limits. Notable exceedance among residential areas was observed at $8 \mathrm{JCCH}$ (Crown zone) $\left(>1,600 \mathrm{mg} / \mathrm{m}^{2} / \mathrm{d}\right)$. Similarly, two nonresidential sites, 65KG MIN and 27PP (Knights and Heriotdale zones), recorded between 1,400 and $2,000 \mathrm{mg} / \mathrm{m}^{2} / \mathrm{d}$ (Figures 2(b) and 2(f)) on few occasions.

At winter, mean dust levels were generally low at the selected residential sites $\left(143-462 \mathrm{mg} / \mathrm{m}^{2} / \mathrm{d}\right)$. Nevertheless, 8JCCH, 34NENT, and 47CHIA (Crown, Western, and Soweto zones) recorded high dust levels between 1,000 and $2,300 \mathrm{mg} / \mathrm{m}^{2} / \mathrm{d}$ on some occasions. Three residential sites (23IMP, 27PP, and 65KG MIN; Heriotdale and Knights zones) equally recorded high dust levels ranging from 1,800 to $2,400 \mathrm{mg} / \mathrm{m}^{2} / \mathrm{d}$ occasionally (Figure $2(\mathrm{e})$ ). 


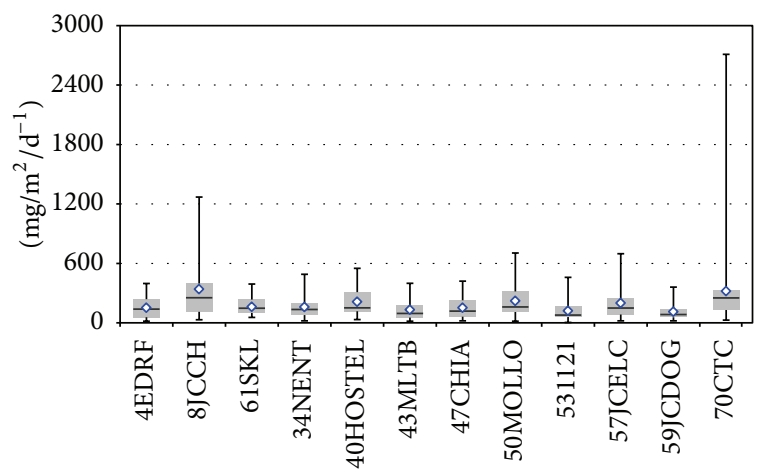

(a) Summer

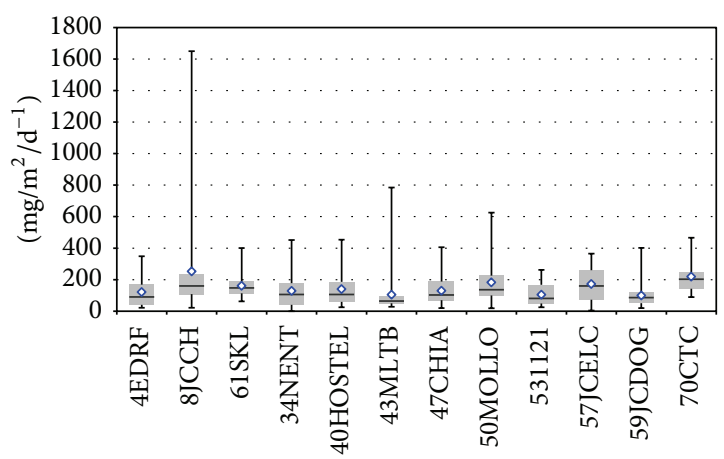

(b) Autumn

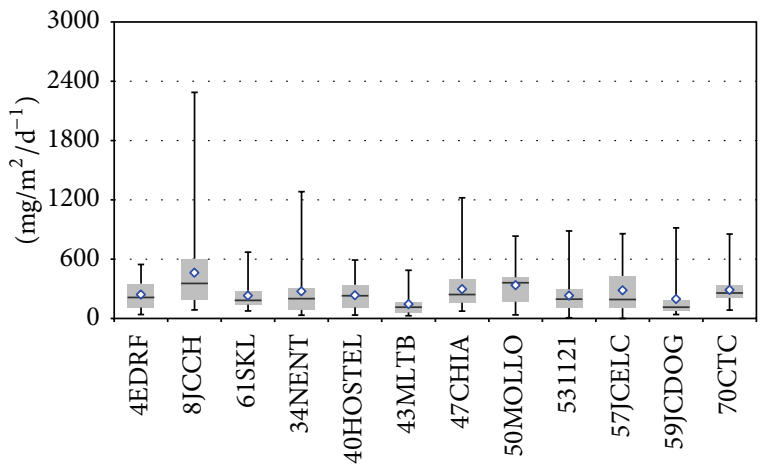

(c) Winter

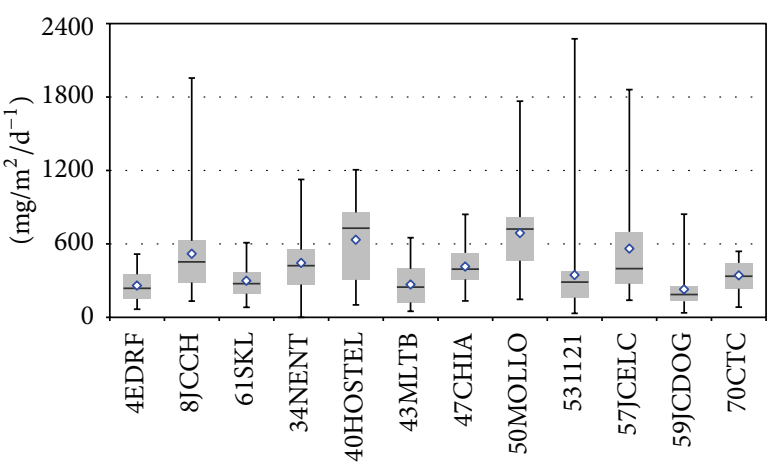

Sites in residential areas

(d) Spring

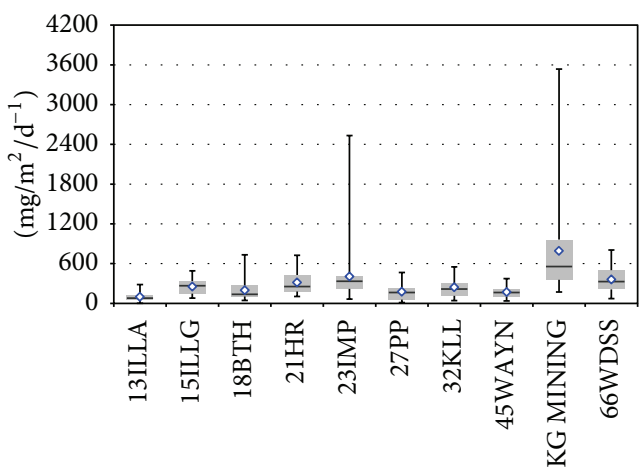

(e) Summer



(f) Autumn

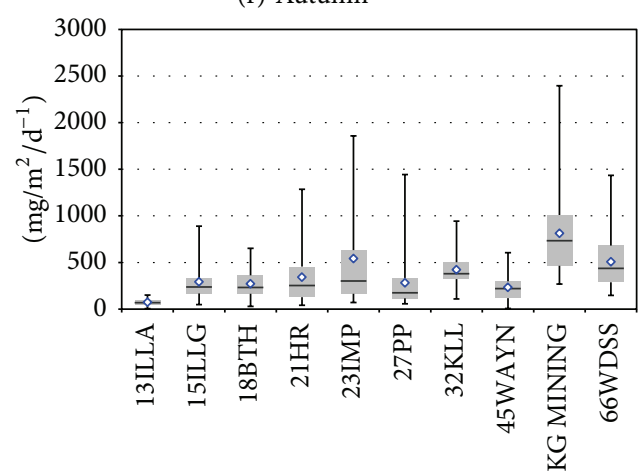

(g) Winter

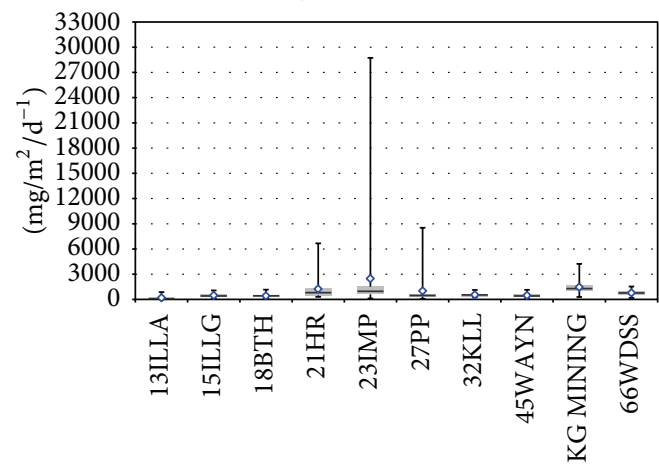

Sites in industrial areas

(h) Spring

Figure 2: Seasonal pattern of dust levels in residential ((a)-(d)) and nonresidential ((e)-(h)) areas. 
TABLE 1: Correlation between dust levels at selected sites and meteorological parameters.

\begin{tabular}{|c|c|c|c|c|c|c|c|c|}
\hline Sample site & Mean rain & Max rain & Min temp & Mean speed & Max speed & Mean direc & Mean hum & Min press \\
\hline \multicolumn{9}{|l|}{ Residential location } \\
\hline 4EDRF & $-0.27^{* *}$ & $-0.30^{* *}$ & $-0.24^{*}$ & $0.31^{* *}$ & $0.31^{* *}$ & $0.23^{*}$ & $-0.44^{* *}$ & $-0.21^{*}$ \\
\hline $8 \mathrm{JCCH}$ & -0.17 & -0.15 & -0.13 & 0.06 & 0.16 & 0.11 & -0.09 & -0.18 \\
\hline 61SKL & $-0.27^{* *}$ & $-0.25^{* *}$ & $-0.20^{*}$ & $0.38^{* *}$ & $0.28^{* *}$ & $0.25^{* *}$ & $-0.51^{* *}$ & -0.11 \\
\hline 34NENT & $-0.20^{*}$ & -0.17 & -0.16 & $0.41^{* *}$ & $0.37^{* *}$ & $0.19^{*}$ & $-0.38^{* *}$ & $-0.21^{*}$ \\
\hline 40HOSTEL & -0.02 & -0.05 & -0.02 & $0.58^{* *}$ & $0.37^{* *}$ & $0.23^{*}$ & $-0.28^{* *}$ & $-0.22^{*}$ \\
\hline 43MLTB & -0.18 & $-0.21^{*}$ & -0.08 & $0.31^{* *}$ & $0.32^{* *}$ & 0.09 & $-0.39^{* *}$ & 0.17 \\
\hline 47CHIA & $-0.35^{* *}$ & $-0.35^{* *}$ & $-0.28^{* *}$ & $0.47^{* *}$ & $0.43^{* *}$ & $0.32^{* *}$ & $-0.59^{* *}$ & $-0.23^{*}$ \\
\hline 50MOLLO & $-0.22^{*}$ & $-0.23^{*}$ & -0.15 & $0.52^{* *}$ & $0.40^{* *}$ & 0.17 & $-0.40^{* *}$ & $-0.19^{*}$ \\
\hline $53-1121$ & -0.12 & -0.07 & $-0.21^{*}$ & $0.27^{* *}$ & $0.31^{* *}$ & 0.15 & $-0.33^{* *}$ & -0.14 \\
\hline 57JCELC & -0.13 & -0.14 & -0.13 & $0.39^{* *}$ & $0.29^{* *}$ & $0.25^{* *}$ & $-0.36^{* *}$ & -0.08 \\
\hline $59 \mathrm{JCDOG}$ & $-0.23^{*}$ & $-0.26^{* *}$ & -0.16 & $0.35^{* *}$ & $0.24^{* *}$ & $0.26^{* *}$ & $-0.44^{* *}$ & -0.13 \\
\hline 70СTC & -0.17 & -0.17 & -0.12 & $0.28^{* *}$ & $0.27^{* *}$ & 0.15 & $-0.42^{* *}$ & -0.12 \\
\hline \multicolumn{9}{|c|}{ Nonresidential locations } \\
\hline 13ILLA & 0.04 & 0.04 & 0.11 & 0.17 & 0.01 & -0.04 & 0.14 & -0.12 \\
\hline 15ILLG & -0.18 & $-0.23^{*}$ & -0.02 & $0.47^{* *}$ & $0.40^{* *}$ & 0.10 & $-0.39^{* *}$ & $-0.22^{*}$ \\
\hline $18 \mathrm{BTH}$ & $-0.28^{* *}$ & $-0.28^{* *}$ & $-0.19^{*}$ & $0.43^{* *}$ & $0.33^{* *}$ & 0.18 & $-0.46^{* *}$ & $-0.23^{*}$ \\
\hline $21 \mathrm{HR}$ & -0.16 & -0.10 & -0.05 & $0.47^{* *}$ & $0.33^{* *}$ & $0.30^{* *}$ & $-0.38^{* *}$ & -0.17 \\
\hline 23IMP & -0.15 & -0.13 & -0.06 & $0.47^{* *}$ & $0.29^{* *}$ & $0.29^{* *}$ & $-0.37^{* *}$ & -0.10 \\
\hline $27 \mathrm{PP}$ & -0.18 & -0.16 & -0.18 & $0.30^{* *}$ & $0.30^{* *}$ & $0.29^{* *}$ & $-0.34^{* *}$ & -0.11 \\
\hline $32 \mathrm{KLL}$ & $-0.32^{* *}$ & $-0.29^{* *}$ & $-0.31^{* *}$ & $0.41^{* *}$ & $0.40^{* *}$ & $0.29^{* *}$ & $-0.52^{* *}$ & -0.17 \\
\hline 45WAYN & $-0.23^{*}$ & $-0.23^{*}$ & -0.12 & $0.47^{* *}$ & $0.38^{* *}$ & 0.06 & $-0.46^{* *}$ & $-0.23^{*}$ \\
\hline 65KG MINING & -0.13 & -0.13 & -0.07 & $0.40^{* *}$ & $0.25^{* *}$ & 0.18 & $-0.29^{* *}$ & -0.10 \\
\hline 66WDSS & -0.19 & -0.17 & -0.17 & $0.34^{* *}$ & $0.27^{* *}$ & 0.08 & $-0.32^{* *}$ & -0.14 \\
\hline
\end{tabular}

*95\% confidence level.

Mean rain: mean rainfall.

Min temp: minimum temperature.

Max speed: maximum wind speed.

Mean hum: mean air humidity.

${ }^{* *} 99 \%$ confidence level.

Max rain: maximum rainfall.

Mean speed: mean wind speed.

Mean direc: mean wind direction.

Min press: minimum air pressure.

The mean dustfall values were highest at all sites during spring. For instance, the mean values monitored at $40 \mathrm{HOS}-$ TEL and 50MOLLO sites were higher than those monitored at 40HOSTEL and 50MOLLO sites that were higher than the limit set for residential areas (Figure 2(d)). While two of the sites did not record any exceedance during the study period, six sites had values well above the limits $(1,120-$ $2,270 \mathrm{mg} / \mathrm{m}^{2} / \mathrm{d}$ ) occasionally. Among the selected nonresidential sites, mean dust levels were higher than the permissible limit at 23IMP and $65 \mathrm{KG}$ MIN $\left(1,500-2,500 \mathrm{mg} / \mathrm{m}^{2} / \mathrm{d}\right)$ locations. Sometimes, dust levels reached between 4,200 and $28,700 \mathrm{mg} / \mathrm{m}^{2} / \mathrm{d}$ at $21 \mathrm{HR}, 23 \mathrm{IMP}, 27 \mathrm{PP}$, and $65 \mathrm{KG}$ MIN sites (Heriotdale and Knights zones) as shown in Figure 2(h).

It was observed that dust episodes experienced at $8 \mathrm{JCCH}$ occurred in the earlier years of the study period (2002 and 2003). Moreover, locations such as 47CHIA, 27PP, and 57JCELC recorded high dust levels in one or two months within a year of the study period. At 50MOLLO, 23IMP, 21HR, 65KG MIN, and 34NENT, the observed dust episodes occurred more frequently between 2005 and 2010. The incident dust episodes in the aforementioned five locations can be adduced to the reprocessing of old and stabilized mine dumps for fine gold extraction. Generally, all sites portrayed a similar monthly pattern of asymmetrical shape curve with relatively low dustfall from December, January to July while August to November recorded high dustfall. Across the seasons, monitored dust levels were of the order: spring $>$ winter $>$ summer $>$ autumn during the study period. This observed pattern is not coincidental but an indication of seasons' influence on dustfall, as the data presented spanned a period of 10 years.

The mean monthly rainfall showed negative correlation with dustfall levels in residential and nonresidential sites (Table 1). The correlation coefficient ranged between $(r)$ -0.19 and $-0.35(P<0.05)$; 66WDSS had the least while 47CHIA had the highest. Other meteorological parameters that showed negative association with dust level included minimum monthly temperature $(r=-0.19-0.31)$, mean 
TABLE 2: Determination of dust fall levels by meteorological parameters at selected sites.

\begin{tabular}{|c|c|c|c|c|}
\hline Sample sites & Wind speed & Humidity & Others & Total \% \\
\hline \multicolumn{5}{|c|}{ Residential location } \\
\hline 4EDRF & - & 0.19 & 0.06 & 25.0 \\
\hline 61SKL & 0.07 & 0.26 & 0.03 & 36.9 \\
\hline 34NENT & 0.17 & 0.09 & - & 25.9 \\
\hline 40HOSTEL & 0.34 & 0.03 & 0.03 & 39.0 \\
\hline 43MLTB & 0.04 & 0.15 & 0.15 & 34.3 \\
\hline 47CHIA & 0.12 & 0.35 & 0.03 & 49.7 \\
\hline 50MOLLO & 0.28 & 0.08 & 0.03 & 38.8 \\
\hline 531121 & - & 0.11 & 0.09 & 19.4 \\
\hline 57JCELC & 0.15 & 0.08 & - & 23.7 \\
\hline $59 \mathrm{JCDOG}$ & 0.07 & 0.19 & - & 26.1 \\
\hline 70CTC & 0.07 & 0.17 & - & 24.0 \\
\hline \multicolumn{5}{|c|}{ Nonresidential locations } \\
\hline 15ILLG & 0.22 & 0.09 & 0.06 & 35.9 \\
\hline $18 \mathrm{BTH}$ & 0.11 & 0.21 & 0.03 & 35.0 \\
\hline $21 \mathrm{HR}$ & 0.22 & 0.08 & - & 29.9 \\
\hline 23IMP & 0.22 & 0.08 & - & 29.4 \\
\hline $27 \mathrm{PP}$ & 0.06 & 0.11 & - & 17.1 \\
\hline $32 \mathrm{KLL}$ & 0.10 & 0.27 & - & 36.9 \\
\hline 45WAYN & 0.22 & 0.13 & 0.10 & 45.5 \\
\hline $65 \mathrm{KG}$ MIN & 0.16 & 0.04 & - & 20.1 \\
\hline 66WDSS & 0.11 & 0.06 & 0.03 & 20.7 \\
\hline
\end{tabular}

monthly humidity $(r=-0.28-0.59)$, and minimum monthly pressure $(r=-0.19-0.23)$.

At residential and nonresidential sites, dustfall levels had positive correlations with mean wind speed and mean wind direction. Among the selected areas, the correlation between mean wind speed and dust levels ranged from $(r) 0.27$ to 0.58 at $53-1121$ and 40 HOSTEL sites, respectively. Mean wind direction and dustfall levels showed correlation coefficient that ranged from $(r) 0.23$ to 0.32 (4EDRF and 47CHIA sites) in residential and nonresidential areas.

There was no significant association between all the meteorological parameters and dustfall at $8 \mathrm{JCCH}$ (Crown zone) and 13ILLA (City Deep) sites. The inability of meteorological parameters to explain dustfall levels at these locations points to overriding influence of factors other than meteorological parameters.

The two significant meteorological parameters that explained dustfall pattern in the study area were mean wind speed and mean relative humidity (Table 2 ). Other parameters that showed low but significant influence on dustfall at a few locations included mean wind direction and minimum air pressure. The determination coefficients of regressing dustfall on mean wind speed ranged from $\left(R^{2}\right) 0.04$ to 0.34 $(4 \%-34 \%)$. Mean wind speed did not explain dustfall levels at $4 \mathrm{EDRF}$ and $53-1121$ sites throughout the study period. The influence of this meteorological parameter was less than $10 \%$ $\left(R^{2}=0.1\right)$ at each of 61SKL, 43MLTB, 55CDOG, 70CTC (residential areas), and 27PP (nonresidential areas) sites. At 50MOLLO and 40HOSTEL (residential areas), 15ILLG,
21HR, 23IMP, and 45WAYN (nonresidential areas) sites, the mean wind speed explained more than $20 \%$ of dustfall levels.

The mean relative humidity was the second meteorological parameter that had significant influence on dustfall levels. At 61SKL, 47CHIA (residential areas), 18BTH, and 32KLL (nonresidential areas) sites, mean relative humidity explained between $21 \%$ and $35 \%\left(R^{2}=0.21-0.35\right)$ of the dustfall levels. At four residential sites and five nonresidential sites, the determination coefficients of relative humidity were less than $\left(R^{2}\right) 0.10$.

It was observed that the influence of mean wind speed and mean relative humidity was contrasting at most sites. In addition, each of the other meteorological parameters that showed significant explanation of dustfall levels was less than $10 \%\left(R^{2}=0.10\right)$ at the sites. The aggregate influence of the significant meteorological parameters was highest at 40HOSTEL, 50MOLLO, 47CHIA (residential areas), and 45WAYN (nonresidential area) sites within the study period. Since meteorological parameters did not explain more than $50 \%$ of dustfall levels at any site in the study area, other factors were responsible for the unexplained percentage.

In order to determine the levels of mean wind speed and mean relative humidity that generated dust episodes (high levels) in residential and nonresidential sites, regression equations were employed. The six residential sites that recorded dust level above $600 \mathrm{mg} / \mathrm{m}^{2} / \mathrm{d}$ (34NENT, 40HOSTEL, 50MOLLO, 53-1121, 57JCELC, and 70CTC) in addition to four nonresidential sites that had dust levels above 
TABLE 3: Determination of dust fall levels by meteorological parameters.

\begin{tabular}{|c|c|c|c|c|c|c|}
\hline Site code & Regression equation & & $\beta$ value & $R$ & $R^{2}(\%)$ & Critical level \\
\hline 34NENT & $Y_{\mathrm{df}}=151.3 X_{\mathrm{ws}}-339.28$ & Model 1 & 150.0 & 0.41 & 17 & $>4 \mathrm{~m} / \mathrm{s}$ (ws) \\
\hline 40HOSTEL & $Y_{\mathrm{df}}=233.3 X_{\mathrm{ws}}-618.93$ & Model 2 & 235.7 & 0.58 & 34 & $>4 \mathrm{~m} / \mathrm{s}$ (ws) \\
\hline 50MOLLO & $Y_{\mathrm{df}}=209.2 X_{\mathrm{ws}}-479.45$ & Model 3 & 217.8 & 0.52 & 25 & $>4 \mathrm{~m} / \mathrm{s}$ (ws) \\
\hline $53-1121$ & $Y_{\mathrm{df}}=-6.4 X_{\mathrm{rh}}+570.27$ & Model 4 & -6.35 & 0.33 & 11 & $<60 \%(\mathrm{rh})$ \\
\hline 57JCELC & $Y_{\mathrm{df}}=158.1 X_{\mathrm{ws}}-336.67$ & Model 5 & 158.1 & 0.39 & 15 & $>4 \mathrm{~m} / \mathrm{s}$ (ws) \\
\hline 70CTC & $Y_{\mathrm{df}}=-4.4 X_{\mathrm{rh}}+526.57$ & Model 6 & -4.41 & 0.35 & 17 & $<50 \%(\mathrm{rh})$ \\
\hline $21 \mathrm{HR}$ & $Y_{\mathrm{df}}=314.0 X_{\mathrm{ws}}-803.97$ & Model 7 & 314.9 & 0.47 & 22 & $>4 \mathrm{~m} / \mathrm{s}$ (ws) \\
\hline 23IMP & $Y_{\mathrm{df}}=410.8 X_{\mathrm{ws}}-1105$ & Model 8 & 401.2 & 0.47 & 22 & $>4 \mathrm{~m} / \mathrm{s}$ (ws) \\
\hline $27 \mathrm{PP}$ & $Y_{\mathrm{df}}=7.0 X_{\mathrm{ws}}-661.96$ & Model 9 & -7.22 & 0.34 & 11 & $<60 \%(\mathrm{rh})$ \\
\hline $32 \mathrm{KLL}$ & $Y_{\mathrm{df}}=-9.1 X_{\mathrm{rh}}-148.32$ & Model 10 & -9.13 & 0.52 & 15 & $>4 \mathrm{~m} / \mathrm{s}(\mathrm{ws})$ \\
\hline $65 \mathrm{KG} \mathrm{MIN}$ & $Y_{\mathrm{df}}=406.7 X_{\mathrm{ws}}-678.37$ & Model 11 & 406.7 & 0.40 & 16 & $>4 \mathrm{~m} / \mathrm{s}$ (ws) \\
\hline
\end{tabular}

Models are significant at $P<0.01$.

df: dustfall; ws: mean wind speed. rh: mean relative humidity.

TABLE 4: Description of the selected sites in the Witwatersrand region.

\begin{tabular}{|c|c|c|c|c|}
\hline $\mathrm{S} / \mathrm{n}$ & Site code & Site name & Site description & Locality/area \\
\hline 1 & 4EDRF & Edgars roof & Residential & Crown \\
\hline 2 & $8 \mathrm{JCCH}$ & Joburg city council house & Residential & Crown \\
\hline 3 & 61SKL & Stockwell & Residential & Crown \\
\hline 4 & 13ILLA & Illman A & Industrial & City Deep \\
\hline 5 & 15ILLG & Illman gate & Industrial & City Deep \\
\hline 6 & $18 \mathrm{BTH}$ & Baumont truck hire & Industrial & Heriotdale \\
\hline 7 & 21HR & Haggie rand & Industrial & Heriotdale \\
\hline 8 & 23IMR & Impala motor repairs & Industrial & Heriotdale \\
\hline 9 & $27 \mathrm{PP}$ & Pick'n pay & Industrial & Heriotdale \\
\hline 10 & $32 \mathrm{KLL}$ & Klem Lloyd Li & Industrial & Heriotdale \\
\hline 11 & 34NENT & Nasrec entrance & Residential & Western \\
\hline 12 & 40HOSTEL & Shaft 17 (hostel) & Residential & Western \\
\hline 13 & 43MLTB & MedLife TB hospital & Residential & Fleurhof \\
\hline 14 & 5WAYN & Wayne plastics & Industrial & Fleurhof \\
\hline 15 & 47CHIA & Chiawelo clinic & Residential & Soweto \\
\hline 16 & 50MOLLO & Mollo house Diepkloof east & Residential & Soweto \\
\hline 17 & 531121 & Matswee house 1121 & Residential & Soweto \\
\hline 18 & 57JCELC & Joburg electricity Department & Residential & Robinson Deep \\
\hline 19 & 59JCDOG & Joburg dog training centre & Residential & Robinson Deep \\
\hline 20 & 65KG MINING & Knights Gold mine & Industrial & Knights \\
\hline 21 & 66WDSS & Wit Deep sand and stone & Industrial & Knights \\
\hline 22 & 70СТC & Continental China & Residential & Knights \\
\hline
\end{tabular}

$1,200 \mathrm{mg} / \mathrm{m}^{2} / \mathrm{d}$ guideline $(21 \mathrm{HR}, 23 \mathrm{IMP}, 27 \mathrm{PP}$, and $65 \mathrm{KG}$ MIN) were used as a case study.

From the graphical plotting of regression models presented in Table 3, mean wind speed higher that $4 \mathrm{~m} / \mathrm{s}$ yielded dust levels well above $600 \mathrm{mg} / \mathrm{m}^{2} / \mathrm{d}$ at 34NENT, 40HOSTEL, 50MOLLO, 57JTCELC, 21HR, 23IMP, and 65KG MIN sites. At 53-1121, 70CTC, and 27PP sites "heavy" dustfall was predicted at mean relative humidity of less than $50 \%$. The application of these predictions to the current dust emission will be based on the assumption that other meteorological and anthropogenic conditions have not changed from the pattern observed during the study period.

\section{Discussion}

Using monthly dustfall data over the period of 10 years in this study, there were variations in dustfall levels among the selected monitoring sites with two sites in Heriotdale zone recording the highest levels. The observed variation among sites may not be unconnected with the distance of locations to nearest tailing facilities, effectiveness of dust abatement measures, and presence of ownerless (uncontrolled) dump in the area, movement of earth materials, and the scale of mining operations. GDARD report [28] indicated similar variations in the level of dustfall among monitoring sites in 
Gauteng province. In related studies, Petrilli [29] and Mishra and Shambhu [14] reported spatial variations in dustfall.

The general low dustfall in autumn, winter, and summer and the high concentration in spring indicate seasonality of dust emission in the study area. Summer, for instance, is characterized by high wind speed but its erosive effect is attenuated by heavy rainfall and strong vertical air mixing; hence low dust erosion and dispersion. Again, autumn is characterized by low speed winds, intermittent rainfalls, and minimal convective activities which produce low dust emission. Although winter months are dry, implying the availability of erodible materials, low speed of the prevailing wind systems yields minimal dust emission and deposition.

Conversely, the high dustfall emission during spring season could be attributed to relatively high wind speed and low rainfall, which are characteristic of the season [25]. Specifically, the highest dustfall recorded by virtually all sites during spring months was attributable to both factors of high erosivity potential of prevailing wind and high erodibility of loose and dry dust. Supporting the observed seasonal pattern of dustfall in the study area, Annegarn and Sithole [17] and Annegarn et al. [1] indicated the spring season as the "high dust period" in the Witwatersrand region. According to Fukagawa et al. [30], atmospheric aerosol portrayed distinct seasonal pattern in Japan. Specifically, the characteristics of wind speed, humidity, and precipitation in each season were shown to influence dust emission [31].

Both mean relative humidity and mean rainfall showed significant negative association with dust fall levels in the Witwatersrand area similar to the findings of Naddafi et al. [32]. Generally, high relative air moisture provides water film that binds dust particles thereby reducing dust erodibility by wind $[33,34]$. Moreover, high moisture content in atmospheric air constitutes additional load carried by wind, hence reducing its speed and erosivity. In Kathmandu valley (India), Giri et al. [35] reported negative correlation between increase of rainfall and humidity with average $\mathrm{PM}_{10}$ emission.

Furthermore, the higher negative correlation between mean relative humidity and dust level than mean rainfall may point to higher impact of moisture in the air than rainfall incidence which is evidently periodic and discontinuous. In agreement with this finding, Petrilli [29] indicated that air humidity was responsible for higher percentage of dustfall variations compared to rainfall.

The positive association between wind speed and dustfall in this study concurs with the inverse relationship between amount of dustfall and wind speed reported by Naddafi et al. [32]. Generally, winds with speed above the threshold for a given particle size are capable of eroding and transporting dust over distance [36], provided other conditions are supportive. High wind speed, therefore, implies high erosion potential for dust emission [37].

Variations in dustfall levels were explained largely by mean relative humidity, mean wind speed, and maximum temperature. According to similar analysis conducted by Yassen [38], rainfall, relative humidity, wind speed, and temperature explained $46 \%$ of dustfall in Kuala Lampur (Malaysia). Other factors such as the type of equipment used, topography of the area, vegetal cover, brittleness and hardness of the materials, and speed and frequency of transport equipment $[13,14]$ could account for the remaining percentage of dustfall variations.

The levels of dustfall at two sites which showed no relationship with meteorological parameters indicated the influence of factors other than meteorology. Such factors could include construction work within the vicinity of the areas, spontaneous dust emission due to equipment failure, and reprocessing of stabilized TSFs for fine gold extraction.

The prediction of $4 \mathrm{~m} / \mathrm{s}$ and above as wind speed that produced dust episode in this study is akin to $16 \mathrm{~km} / \mathrm{h}$ remarked by Annegarn et al. [1] as wind speed required for dust lifting in the study area. Lee and Tchakerian [39] predicted a higher wind speed of $6 \mathrm{~m} / \mathrm{s}$ for initiating blowing dust in the Southern High Plains of the United States. The disparity in wind speed predicted by these authors was due to the difference in the type of earth materials that were studied.

\section{Conclusion}

Aeolian dust from TSFs in the Witwatersrand area varied among the sites and across the seasons. The two most significant parameters that influenced dustfall at most sites in the study area were mean relative humidity and mean wind speed. While mean humidity showed negative correlation, the mean wind speed was positive. Although the coefficient of determination derived from regression analysis revealed differences in percentage contribution of the four significant meteorological parameters, sites with low impact of mean humidity had relatively higher percentage contribution of mean wind speed. Critical levels of mean humidity and mean wind speed that yielded dust episodes were predicted at selected sites.

For environmental planning purposes, current mitigation measures should be manipulated in relation to levels of air humidity and wind speed especially at spring months for dust emission reduction. Moreover, with meteorological parameters explaining about half the pattern of dustfall, there are other factors that contributed to the occurrence of dust episodes in the Witwatersrand region. A more effective dust mitigation measures and community adaptation training should be introduced in residential areas that receive high dust emissions from TSFs. Finally, network of mobile weather stations that could provide early warning signals based on wind speed and air humidity data should be installed within the residential areas that experience frequent dust episodes.

\section{Acknowledgments}

The authors appreciate the South African Meteorological Agency and Crown-Gold Dust Monitoring Project (CRUST) for data provision.

\section{References}

[1] H. J. Annegarn, A. D. Surridge, H. S. P. Hlapolosa, D. J. D. V. Swanepoei, and A. R. Horne, "A review of 10 years of 
environmental dust monitoring at Crown Mines," Journal of the Mine Ventilation Society of South Africa, vol. 44, no. 3, p. 46, 1991.

[2] H. Coetzee, "Radiometric surveying in the vicinity of witwatersrand gold mines," in Proceedings of the 3rd International Seminar on Mine Closure, A. Fourie, M. Tibbett, I. Weiersbye, and P. Dye, Eds., pp. 617-629, 2008.

[3] M. E. Ojelede, H. J. Annegarn, and M. A. Kneen, "Evaluation of aeolian emissions from gold mine tailings on the Witwatersrand," Aeolian Research, vol. 3, no. 4, pp. 477-486, 2012.

[4] NSW, "About dust-test: storms," 2003, http://www.bom.gov.au/ nsw/sevwx/facts/dust.shtml.

[5] S. Ozkan and B. Ipekoglu, "Investigation of environmental impacts of tailings dams," Environmental Management and Health, vol. 13, no. 3, pp. 242-248, 2002.

[6] K. Naicker, E. Cukrowska, and T. S. McCarthy, "Acid mine drainage arising from gold mining activity in Johannesburg, South Africa and environs," Environmental Pollution, vol. 122, no. 1, pp. 29-40, 2003.

[7] R. Friedrich, "Natural and biogenic emissions of environmentally relevant atmospheric trace constituents in Europe," Atmospheric Environment, vol. 43, no. 7, pp. 1377-1379, 2009.

[8] C. McKenna Neuman, J. W. Boulton, and S. Sanderson, "Wind tunnel simulation of environmental controls on fugitive dust emissions from mine tailings," Atmospheric Environment, vol. 43, no. 3, pp. 520-529, 2009.

[9] B. Howard and I. Cameroon, Best Practice Environmental Management in Mining: Dust Control, Australian Department of Environment, 1998.

[10] L. W. James, "Health hazards of mining and quarrying," 2011, http://www.ilo.org/safework/.

[11] X. Wang, E. Yano, K. Nonaka, M. Wang, and Z. Wang, "Respiratory impairments due to dust exposure: a comparative study among workers exposed to silica, asbestos, and coal mine dust," American Journal of Industrial Medicine, vol. 31, pp. 495$502,1997$.

[12] American Thoracic Society (ATS), "Adverse effects of crystalline silica exposure: American Thoracic Society Committee of the Scientific Assembly on Environmental Occupational Health," American Journal of Respiratory and Critical Care Medicine, vol. 155, no. 2, pp. 761-765, 1997.

[13] J. G. Watson and J. C. Chow, "Reconciling urban fugitive dust emissions inventory and ambient source contribution estimates: summary of current knowledge and needed research," Desert Research Institute Document 6110.4F, DRI, Las Vegas, Nev, USA, 2000.

[14] P. C. Mishra and J. H. A. Shambhu, "Dust dispersion modeling in open-cast Coal mines and control of dispersion in Mahanadi Coalfields of Orissa," in Proceedings of the International Conference on Environment, Energy and Development: From Stockholm to Copenhagen and Beyond, Sambalpur University, December 2010.

[15] L. Wallace and W. Ott, "Personal exposure to ultrafine particles," Journal of Exposure Science and Environmental Epidemiology, vol. 21, no. 1, pp. 20-30, 2011.

[16] Y. Scorgie, "Air quality assessment of the Durban Roodepoort Deep (DRD), West Rand Consolidated (WRC) and Prince Tailing Complexes and Review of environmental management measures and programmes," Tech. Rep. APP/05/LRC-01, Legal Resources Centre, Johannesburg, South Africa, 2006.
[17] H. J. Annegarn and S. J. Sithole, "Dust monitoring and mitigation on gold tailings reclamation," in Proceedings of the Mine Ventilation Society Symposium, pp. 1-13, 2002 February.

[18] "Minerals Act of 1991," Government Gazatte, vol. 311, no. 13253, 2011, http://www.info.gov.za/view/.

[19] "Minerals and petroleum resources acts of 2002," 2012, http://www.bclr.com/pdf/legislation/mineral_and_petroleum resources.pdf.

[20] A. S. Rossouw, D. G. Furniss, H. J. Annegarn, I. M. Weiersby, U. Ndolo, and M. Cooper, "Evaluation of a 20-40 year old mine tailings rehabilitation project on the Witwatersrand, South Africa," in Mine Closure, A. B. Fourie and M. Tibett, Eds., pp. 123-136, Australian Centre for Geomechanics, Perth, Australia, 2009.

[21] M. E. Ojelede, H. J. Annegarn, and M. Mlondo, "Grain size analysis and elemental composition of the $\mathrm{PM}_{10}$ and $\mathrm{PM}_{2.5}$ fractions of gold tailings," in Proceeding of the $3 r$ International Seminar on Mine Closure, A. Fourie, M. Tibbett, I. Weiersbye, and P. Dye, Eds., pp. 609-619, 2008.

[22] E. M. Cukrowska, J. Lusilao-Makiese, H. Nsengimana, H. Tutu, D. Amouroux, and E. Tessier, "Mercury and tin speciation in the environment of gold tailings dumps in the Central Rand, Johannesburg," in Proceeding of the 3rd International Seminar on Mine Closure, A. Fourie, M. Tibbett, I. Weiersbye, and P. Dye, Eds., pp. 673-680, 2008.

[23] P. Gwaze, G. Helas, H. J. Annegarn, J. Huth, and S. J. Piketh, "Physical, chemical and optical properties of aerosol particles collected over Cape Town during winter haze episodes," South African Journal of Science, vol. 103, no. 1-2, pp. 35-43, 2007.

[24] South African National Standard, Ambient Air Quality-Limits for Common Pollutants, SANS 1929:2005, SANS, Pretoria, South Africa, 1.1 edition, 2005.

[25] R. A. Preston-Whyte and P. D. Tyson, The Atmosphere and Weather of Southern Africa, Oxford University Press, Cape Town, South Africa, 1988.

[26] "Standard methods for collection and analysis of dust-fall," in Annual Book of ASTM Standards, vol. 11.03, ASTM D1739, American Society for Testing and Materials, Philadelphia, Pa, USA, 1982.

[27] W. L. Neuman, Social Research Methods: Qualitative and Quantitative Approaches, Allyn and Bacon, Boston, Mass, USA, 4th edition, 2000.

[28] "Conceptual study on reclaimed mine land," GDARD Report, Gauteng Provincial Government, 2009.

[29] F. L. Petrilli, "Methods of measuring sulfur dioxide, dustfall and suspended matter in city air, and their use in the study of air pollution in Italy," Bulletin of the World Health Organization, vol. 26, pp. 495-512, 1962.

[30] S. Fukagawa, H. Kuze, G. Bagtasa et al., "Characterization of seasonal variation of tropospheric aerosols in Chiba, Japan," Atmospheric Environment, vol. 40, no. 12, pp. 2160-2168, 2006.

[31] C. Chang, "Characteristics and emission factors of fugitive dust at gravel processing sites," Aerosol and Air Quality Research, vol. 6, no. 1, pp. 15-29, 2006.

[32] K. Naddafi, R. Nabizadeh, Z. Soltanianzadeh, and M. H. Ehrampoosh, "Evaluation of dust-fall in arid air of Yazd," Journal of Environmental Health Science Engineering, vol. 3, no. 3, pp. 161168, 2006.

[33] J. A. Lee, B. L. Allen, R. E. Peterson, J. M. Gregory, and K. E. Moffett, "Environmental controls on blowing dust direction at Lubbock, Texas, USA," Earth Surface Processes \& Landforms, vol. 19, no. 5, pp. 437-449, 1994. 
[34] J. Smith and K. Lee, "Soil as a source of dust and implications for human health," Advances in Agronomy, vol. 80, pp. 1-32, 2003.

[35] D. Giri, V. Krishna Murthy, and P. R. Adhikary, “The influence of meteorological conditions on $\mathrm{PM}_{10}$ concentrations in Kathmandu Valley," International Journal of Environmental Research, vol. 2, no. 1, pp. 49-60, 2008.

[36] K. Saxton, D. Chandler, L. Stetler, B. Lamb, C. Claiborn, and B.H. Lee, "Wind erosion and fugitive dust fluxes on agricultural lands in the Pacific Northwest," Transactions of the American Society of Agricultural Engineers, vol. 43, no. 3, pp. 623-630, 2000.

[37] J. M. Prospero, M. Uematsu, and D. L. Savoie, "Mineral aerosol transport to the Pacific Ocean," in Chemical Oceanography, J. P. Riley, R. Chester, and R. A. Duce, Eds., pp. 188-218, Academic Press, San Diego, Calif, USA, 1989.

[38] M. E. Yassen, Analysis of climatic conditions and air quality observations in Kuala Lumpur and Petaling Jaya, Malaysia, during 1983-1997 [M.S. thesis], Universiti Kebangsaan Malaysia, 2000.

[39] J. A. Lee and V. P. Tchakerian, "Magnitude and frequency of blowing dust on the Southern High Plains of the United States, 1947-1989," Annals of the Association of American Geographers, vol. 85, no. 4, pp. 684-693, 1995. 

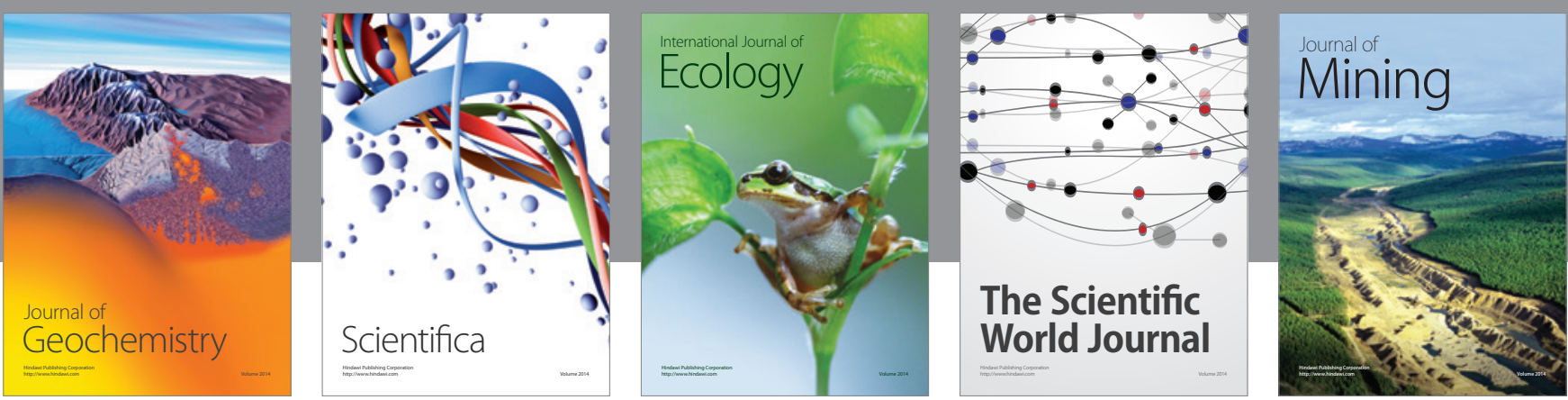

The Scientific World Journal
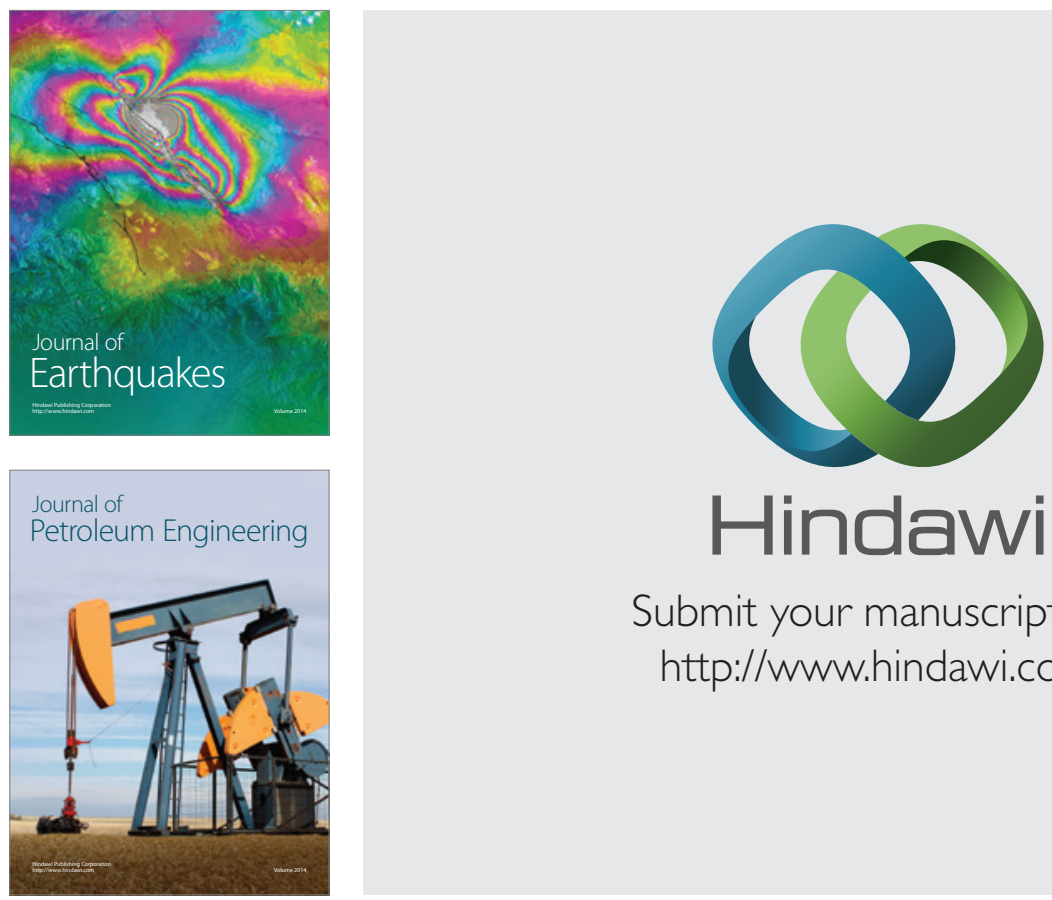

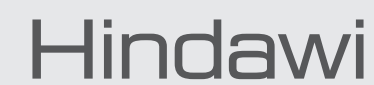

Submit your manuscripts at

http://www.hindawi.com
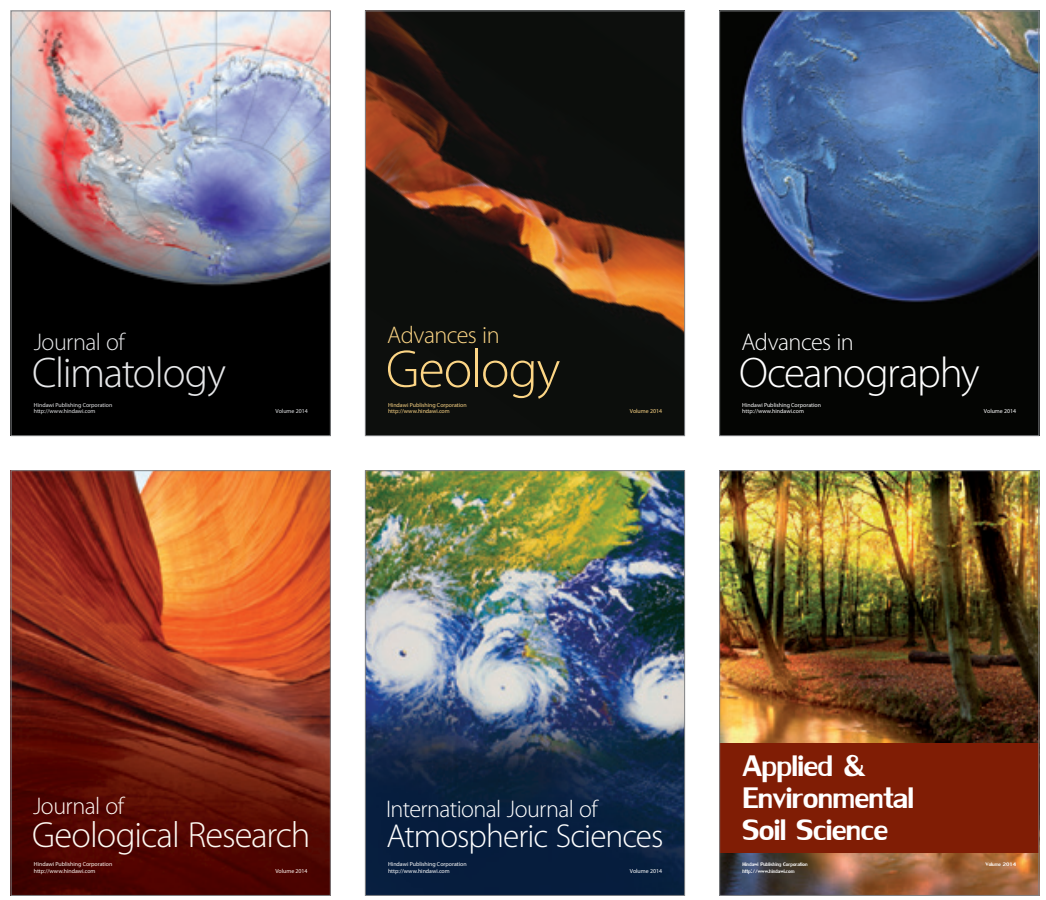
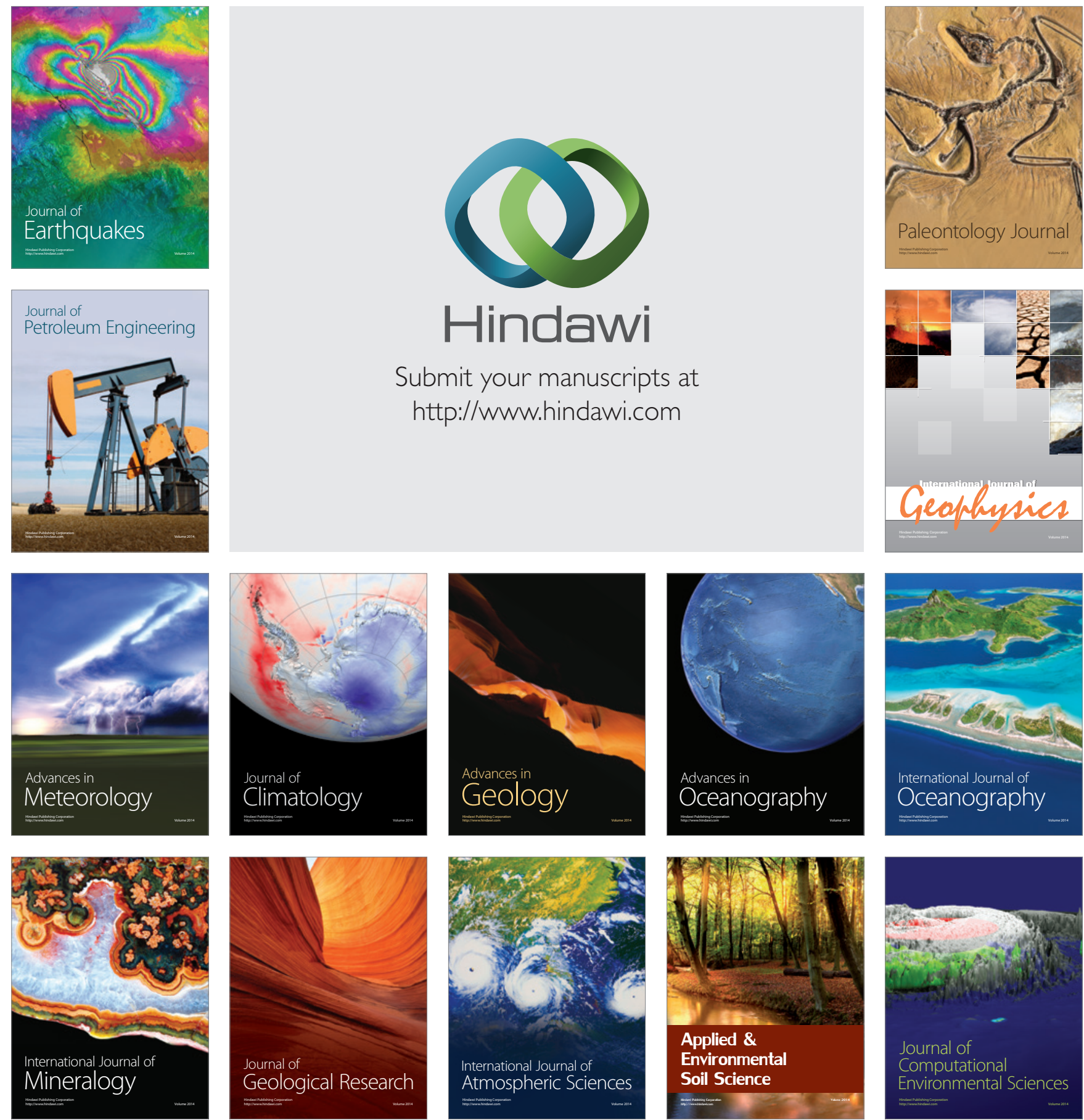